\title{
EARLY ASSORTMENT OF ROUTES FOR TRANSFER OF PACKETS IN COMMUNICATION NETWORKS
}

\author{
Ch. Sudhakar ${ }^{1}$, N. Thirupathi Rao ${ }^{1}$ and Debnath Bhattacharyya ${ }^{1}$ \\ ${ }^{1}$ Department of Computer Science \& Engineering \\ Vignan's Institute of Information Technology (A) \\ Visakhapatnam, AP, India \\ nakkathiru@gmail.com,debnathb@gmail.com
}

\begin{abstract}
Information concentrated e-science synchronised efforts frequently requires the exchange of huge records with unsurprising execution. To address this issue, the authors tried to outline booking calculations for mass information move in examine systems for e-science. Because of their little sizes, the exploration systems can bear the cost of an incorporated asset administration stage. In our analysis, each mass exchange work asked can be made ahead of time to the focal system controller that indicates a begin time and an end time. If concede that the system assurances to finish the exchange before the end time. In any case, there is adaptability in how the whole exchange is completed, in the data transmission task on each permitted way of the activity on each time interim. Moreover, it is up to the booking calculation to choose this. To enhance the system asset use or lower the activity dismissal proportion, the system controller takes care of advancement issues in settling on AC and booking choices. Current plan joins the accompanying components into a permanent improvement based system like progress ahead of time, multipath steering and transmission capacity reassignment through occasional re-optimisation. The assessment of the calculation was done by considering both system effectiveness and the execution level of individual exchange.
\end{abstract}

Keywords - Communication networks, bulk arrivals, bulk transfers, reservations

\section{INTRODUCTION}

The progress of communication and networking advancements together with the registering and capacity advances is drastically changing the ways how relevant research is directed [1]. Another term e-science has developed to portray the extensive scale science helped out through dispersed worldwide joint efforts empowered by systems. The expecting was reached by access to substantial scale information accumulations, registering assets, and superior perception". All around cited e-science (and the related framework registering) cases incorporate high-vitality, high-energy nuclear physics (HEP), radio stargazing, geosciences and atmosphere ponders [2]. The requirement for transporting an expansive volume of information in e-science has very much contended.

To address the issue of e-science, the current article contemplates admission control and booking calculations for high transmission capacity information moves in to look into systems[3]. The outcomes will not just propel the learning and procedures here yet also compliment the convention, engineering and framework extend. As of now, the progress in the help of e-science and matrix processing by giving more productive system asset reservation and administration calculations to the outcomes. The currently considered AC

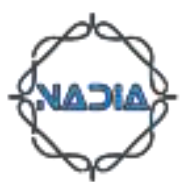


and planning calculations handle two classes of occupations, mass information exchange and those that require a base data transfer capacity make sure. The Mass exchange is not touchy to the system delay yet might be delicate to the conveyance due date. It is valuable for disseminating high volumes of logical information, which at present frequently depends on ground transportation of the capacity media. The way toward deciding the way of information exchange is known as scheduling [4].

To arrangement data transmission for BDT, the two fundamental issues are to designate transfer speed in time and space. These two issues are comprehended by data transmission planning and way calculation calculations individually. Two essential provisioning modes are usually recognized are as follows:

(1) on-request mode: An association asks for is made when required, and it is then acknowledged or denied relying upon the present data transmission accessibility. Arriving demands are lined until their distribution.

(2) in-advance mode: An association asks for is allowed for future availabilities given data transmission allotment plan; arriving demands are planned for the future when they arrive. Numerous issues identified with data transfer capacity allotment and way calculation are NP-complete. Lin et al. portray two essential booking issues: settled way with variable transmission capacity and variable way with variable data transfer capacity to limit the exchange end time of a given information estimate. They demonstrate that the two issues are NP-finished and they propose ravenous heuristic calculations to understand them.

The on-request mode can be viewed as a different instance of ahead of time mode. In this manner, concentrating on bookings ahead of time does not limit our degree. Making bookings ahead of time of system assets is not later. The principal issue is the Flightiness of the steering conduct. Nonetheless, with the development of the MPLS standard activity building and definite steering highlights, it ends up conceivable to disengage the reservation administration from the system layer, along these lines prompting less demanding interoperability for the ABR administration frameworks [5].

For booking ahead of time, extraordinary BDT planning systems can be utilized: internet planning where demands are handled when they arrive or occasional cluster planning where they are booked with a specific periodicity. Diverse time models can likewise be utilized: constant instance replica and discrete models with settled schedule vacancies (cuts) amid which the asset designations are comparable [6].

A few different issues identified with ABRs have been investigated: adaptation to noncritical failure, rerouting methodologies, stack adjusting systems, time-move reservations, and so forth. For the occasion, none of the proposed arrangements considers the system's vitality utilisation as an outstanding issue which should impact the plan of every calculation identified with the system's administration, from planning to the steering.

\section{RELATED WORK}

The existing framework permits the affirmation of new demands and transmission capacity reallocation to existing employment while not abusing the end-time prerequisites of the current occupations. In the first place, it crosses out the current stream task to the old employment on the future time cuts and reestablishes the system to its different limit. The data transmission of existing occupations might be reallocated in the single connection case however not in the system case. The courses and transfer speed of existing occupations are unaltered.

In the proposed framework, admission control and booking calculations handle two classes of employment, mass information exchange etc. A Mass exchange isn't touchy to the system delay yet might be delicate to the conveyance due date. It is helpful for disseminating high volumes of logical information, which right now regularly depends on 
ground transportation of the capacity media. The MBG class is helpful for constant rendering or perception of information remotely. In our system, the calculations for taking care of mass exchange additionally contain the fundamental elements of those for taking care of the MBG class. Hence, we will just spotlight on the mass exchange. One recognising highlight in this investigation is that each activity demand can be made ahead of time. If an occupation is conceded, as controlled by the AC calculation, the system ensures that it will complete the information exchange for the activity before the asked for the end time. The test is the means by which to give this assurance while keeping up the skillful use of the system assets and keeping the demand dismissal proportion low. The way toward deciding the way of information exchange is known as planning. The outcome is enormously enhanced productivity in arranging asset use. Creating comparable conventions and adding new segments to the current toolbox in the help of our calculations are among the future assignments.

In this paper, admission control and planning calculations for high transmission capacity information move in explore systems. The outcomes will not just propel the information and methods here yet also compliment the convention, engineering, and foundation extends. Currently, the progress was observed in the help of e-science and matrix processing by giving more productive system asset reservation and administration calculations. Current AC and booking calculations handle two classes of employment, mass information exchange and those that require a base transfer speed ensure. The Mass exchange is not touchy to the system delay however might be delicate to the conveyance due date. It is valuable for circulating high volumes of logical information, which at present frequently depends on ground transportation of the capacity media. The way toward deciding the way of information exchange is known as scheduling.

\section{MODULES DESCRIPTION}

The main modules in the current article are as follows,

\section{FUNCTIONAL REQUIREMENTS:}

\subsection{PATH RESERVATION}

In this module, the user's tries to hold way to path reservation subtle elements begin time, end-time, date and way. Before holding way, the admission control checks accessibility for determined way officially held or not. Reservation plot for mass exchange, which checks reserve red occupation time with asked for begin time and end time for the activity and tries to discover a way that can suit the full employment on that interim. In Reservation frame it will gather the begin time, end time, date, goal, source to check for accessibility. On the off chance, that it is not accessible, it will dismiss the activity and request that the client holds later or some other way. On the off chance that it prepared to acknowledge the activity then, it will check for the record size and time length given by the client. At that point in ascertaining the time cut with transmission capacity and record estimate. Else it will request that the client gives the right time term.

\subsection{MINIMUM BANDWIDTH ALLOCATION}

Admission Control and planning calculations handle two classes of employment, mass information exchange and assign least data transmission to ensure for a specific time in a specific way. So information can be moved within the opportunity to the goal. Others can not utilise the transmission capacity. The requirement for effective system asset usage is particularly significant with regards to bookings ahead of time and expansive record sizes or steady streams. As contended at there is an unfortunate wonder known as transfer speed fracture. The least complicated case of data transfer capacity discontinuity happens when the interim between the end time of one employee and the start of another activity is 
not sufficiently long for some other activity asks. A mass exchange demand may alternatively indicate a base data transfer capacity as well as a most extreme transmission capacity. Significantly, more parameters can be included if necessary like an expected range for the requested measure or for the last days when the exact data is obscure.

\subsection{TIME MANAGEMENT}

Employment's point of view, it is alluring to have a shorter reaction time. Each activity demand can be made ahead of time and can determine a begin time and an end time. The data transmission allocated to a specific way of an occupation stays steady for the whole time cut. However, it might change the exchange time. That implies the exchange might be finished inside the time and remaining time reservation will be assigned for (open clients).

REJECTION PROPORTION: This is the proportion of the number of occupations rejected and adds up some employment demands. From the system's viewpoint, it is alluring to concede however many employments as could be expected under the circumstances. From the client's viewpoint, it is alluring to have a little possibility of employment dismissal.

\subsection{ADMISSION CONTROL}

To address the issue of e-science, this paper thinks about admission control (AC) and planning calculations for high transmission capacity information exchanges (otherwise called occupations) to look into systems. Confirmation controller is brought together separate which oversee work reservations and Transfers. It gathers reservation asks for from hub and check for accessibility then it dismisses or acknowledges the activity. It enhances the system asset use or lowers the activity dismissal proportion; the system controller takes care of advancement issues in settling on AC and booking choices. Air conditioning calculation, the system ensures that it will complete the information exchange for the activity before the asked for the end time.

\section{NON-FUNCTIONAL REQUIREMENTS}

Contingent upon the consequences of the underlying examination the overview is presently extended to a more point by point practicality think about. "FEASIBILITY STUDY" is a trial of framework proposition as indicated by its workability, the effect of the association and viable utilisation of the assets.

Three key considerations are involved in the feasibility analysis:

\section{TECHNICAL FEASIBILITY}

Specialised practicality fixates on the current PC framework (equipment, programming, and so on.) and to what degree it can bolster the proposed expansion. This includes monetary contemplations to oblige specialized upgrades. If the financial backing is a certain limitation, at that point, the undertaking is judged not attainable.

The present task is considered in fact to double as the specialised necessities, which could be fulfilled effectively. We have enough innovative perspectives to execute the above issue. Consequently, the task is achievable.

\section{OPERATIONAL FEASIBILITY}

Proposed ventures are valuable just on the off chance that they can be turned into data frameworks that will meet the association's working prerequisites. Just expressed, this trial of achievability inquires as to whether the framework will work when it is produced and introduced. 


\section{ECONOMIC FEASIBILITY}

The monetary examination is the most habitually utilized technique for assessing the adequacy of a hopeful framework. All the more regularly known as cost/advantage investigation, the technique is to decide the advantages and reserve funds that are normal from an applicant framework and contrast them and expenses. If advantages out measure cost, at that point, the choice is made to outline and execute the framework. Something else, encourage avocation or modifications in the proposed framework should be made on the off chance that it is to have a possibility of being affirmed. This is a progressing exertion that enhances in precision at each period of the framework life cycle.

\subsection{ADAPTABILITY}

It is an alluring property of a framework, a system, or a procedure, which demonstrates its capacity to either deal with developing measures of work elegantly or to be promptly expanded. An undifferentiated of significance is inferred, where the versatility of an organisation infers that the basic plan of action offers the potential for financial development inside the organisation.

\subsection{RELIABILITY}

A man or framework can perform and keep up its capacities in customary conditions and also threatening or unusual conditions.

\subsection{INTEGRITY}

It is idea needs to do with apparent consistency of activities, values, strategies, measures, standards, desires and result capacity to accomplish their objectives. An esteem framework's reflection profundity and scope of appropriate connection may likewise work as critical factors in distinguishing trustworthiness because of their coinciding or absence of compatibility with accurate perception. An esteem framework may develop after some time while holding trustworthiness if the individuals who uphold the qualities represent and resolve irregularities.

\section{TEST CASES}

\begin{tabular}{|c|c|c|c|c|c|c|c|}
\hline Module & Test Scenarios & $\begin{array}{l}\text { Test } \\
\text { Cas } \\
\text { e ID }\end{array}$ & $\begin{array}{l}\text { Test Case } \\
\text { Description }\end{array}$ & Test Data & Steps & $\begin{array}{l}\text { Expecte } \\
\text { d } \\
\text { Results }\end{array}$ & Results \\
\hline $\begin{array}{l}\text { Reservati } \\
\text { on }\end{array}$ & $\begin{array}{l}\text { Verify the } \\
\text { buttons and } \\
\text { text boxes for } \\
\text { reservation. }\end{array}$ & 1 & $\begin{array}{l}\text { Ensure that the } \\
\text { username and } \\
\text { password }\end{array}$ & $\begin{array}{l}\text { The advance } \\
\text { application } \\
\text { should be } \\
\text { available }\end{array}$ & $\begin{array}{l}\text { 1. Open the } \\
\text { application } \\
\text { 2. Verify the } \\
\text { buttons, and text } \\
\text { boxes are } \\
\text { available }\end{array}$ & $\begin{array}{l}\text { Login } \\
\text { Form } \\
\text { should } \\
\text { be } \\
\text { successf } \\
\text { ul. }\end{array}$ & $\begin{array}{l}\text { Login } \\
\text { Form was } \\
\text { successful }\end{array}$ \\
\hline $\begin{array}{l}\text { Reservati } \\
\text { on }\end{array}$ & $\begin{array}{l}\text { Verify the } \\
\text { graph of the } \\
\text { system. }\end{array}$ & 2 & $\begin{array}{l}\text { Ensure that the } \\
\text { creation of a } \\
\text { graph of the } \\
\text { system. }\end{array}$ & $\begin{array}{l}\text { The advance } \\
\text { application } \\
\text { should be } \\
\text { available }\end{array}$ & $\begin{array}{l}\text { 1. Open the } \\
\text { application } \\
\text { 2. Verify that the } \\
\text { application is } \\
\text { navigated to the } \\
\text { next page }\end{array}$ & $\begin{array}{l}\text { The } \\
\text { applicati } \\
\text { on } \\
\text { should } \\
\text { be } \\
\text { navigate } \\
\text { d to the } \\
\text { next } \\
\text { page }\end{array}$ & $\begin{array}{l}\text { Applicati } \\
\text { on } \\
\text { navigated } \\
\text { to the } \\
\text { next page } \\
\end{array}$ \\
\hline
\end{tabular}




\begin{tabular}{|c|c|c|c|c|c|c|c|}
\hline $\begin{array}{l}\text { Reservati } \\
\text { on }\end{array}$ & $\begin{array}{l}\text { Verify the } \\
\text { checklist Node }\end{array}$ & 3 & $\begin{array}{l}\text { Ensure that the } \\
\text { list node for the } \\
\text { Destination. }\end{array}$ & $\begin{array}{l}\text { The advance } \\
\text { application } \\
\text { should be } \\
\text { available }\end{array}$ & $\begin{array}{l}\text { 1. Open the } \\
\text { application } \\
\text { 2. Verify that the } \\
\text { list box of the } \\
\text { destination node } \\
\text { is available or } \\
\text { not. }\end{array}$ & $\begin{array}{l}\text { Verified } \\
\text { list box } \\
\text { of the } \\
\text { destinati } \\
\text { on node } \\
\text { Should } \\
\text { be } \\
\text { availabl } \\
\text { e }\end{array}$ & $\begin{array}{l}\text { Verified } \\
\text { list box of } \\
\text { the } \\
\text { destinatio } \\
\text { n node }\end{array}$ \\
\hline $\begin{array}{l}\text { Reservati } \\
\text { on }\end{array}$ & $\begin{array}{l}\text { Verify the } \\
\text { Start Time, } \\
\text { End Time and } \\
\text { Date }\end{array}$ & 4 & $\begin{array}{l}\text { Ensure that the } \\
\text { start time, end } \\
\text { time for } \\
\text { reaching the } \\
\text { messages to the } \\
\text { particular } \\
\text { destination. }\end{array}$ & $\begin{array}{l}\text { The advance } \\
\text { application } \\
\text { should be } \\
\text { available }\end{array}$ & $\begin{array}{l}\text { 1. Open the } \\
\text { application } \\
\text { 2. Select the start } \\
\text { time, end time } \\
\text { and date. } \\
\text { 3. Verify the } \\
\text { start time and } \\
\text { end time, date } \\
\text { that is selected at } \\
\text { the time of } \\
\text { reservation. }\end{array}$ & $\begin{array}{l}\text { Verified } \\
\text { the list } \\
\text { boxes } \\
\text { for start } \\
\text { time, } \\
\text { end } \\
\text { time, } \\
\text { the date } \\
\text { should } \\
\text { be } \\
\text { availabl } \\
\text { e }\end{array}$ & $\begin{array}{l}\text { Verified } \\
\text { the list } \\
\text { boxes for } \\
\text { start time, } \\
\text { end time, } \\
\text { date } \\
\text { should be } \\
\text { available }\end{array}$ \\
\hline $\begin{array}{l}\text { Reservati } \\
\text { on }\end{array}$ & $\begin{array}{l}\text { Verify the } \\
\text { Check } \\
\text { Availability }\end{array}$ & 5 & $\begin{array}{l}\text { Ensure that the } \\
\text { path is available } \\
\text { or not }\end{array}$ & $\begin{array}{l}\text { The advance } \\
\text { application } \\
\text { should be } \\
\text { available }\end{array}$ & $\begin{array}{l}\text { 1. Open the } \\
\text { application } \\
\text { 2.click on check } \\
\text { availability } \\
\text { 3. Verify that } \\
\text { the path is } \\
\text { available or not. }\end{array}$ & $\begin{array}{l}\text { Verified } \\
\text { that the } \\
\text { reserved } \\
\text { path } \\
\text { should } \\
\text { be } \\
\text { availabl } \\
\text { e }\end{array}$ & $\begin{array}{l}\text { Verified } \\
\text { that the } \\
\text { reserved } \\
\text { the path } \\
\text { should be } \\
\text { available }\end{array}$ \\
\hline $\begin{array}{l}\text { Reservati } \\
\text { on }\end{array}$ & $\begin{array}{l}\text { Verify } \\
\text { Reserve } \\
\text { Button }\end{array}$ & 6 & $\begin{array}{l}\text { Ensure that the } \\
\text { click on the } \\
\text { reserve button } \\
\text { then displays } \\
\text { window box } \\
\text { reserve path is } \\
\text { successful or } \\
\text { not. }\end{array}$ & $\begin{array}{l}\text { The advance } \\
\text { application } \\
\text { should be } \\
\text { available. }\end{array}$ & $\begin{array}{l}\text { 1. Open the } \\
\text { application } \\
\text { 2. Click on the } \\
\text { reserve button } \\
\text { 3. Verify the } \\
\text { reserve path is } \\
\text { successful } \\
\text { getting or not. }\end{array}$ & $\begin{array}{l}\text { Verified } \\
\text { the } \\
\text { reserve } \\
\text { path } \\
\text { should } \\
\text { be } \\
\text { successf } \\
\text { ul }\end{array}$ & $\begin{array}{l}\text { Verified } \\
\text { the } \\
\text { reserve } \\
\text { path } \\
\text { successful }\end{array}$ \\
\hline $\begin{array}{l}\text { Reservati } \\
\text { on }\end{array}$ & $\begin{array}{lr}\text { Verify } & \text { the } \\
\text { Source } & \text { Text } \\
\text { Field } & \end{array}$ & 7 & $\begin{array}{l}\text { Ensure that the } \\
\text { text field having } \\
\text { a correct source } \\
\text { or not }\end{array}$ & $\begin{array}{l}\text { The advance } \\
\text { application } \\
\text { should be } \\
\text { available }\end{array}$ & $\begin{array}{l}\text { 1. Open the } \\
\text { application } \\
\text { 2. Enter the data } \\
\text { into the text } \\
\text { fields. } \\
\text { 3. Verify the text } \\
\text { fields are having } \\
\text { a correct source } \\
\text { or not. }\end{array}$ & $\begin{array}{l}\text { Verified } \\
\text { the text } \\
\text { fields of } \\
\text { the } \\
\text { source } \\
\text { are } \\
\text { getting } \\
\text { the } \\
\text { values } \\
\text { incorrec } \\
\text { t } \\
\text { format. }\end{array}$ & $\begin{array}{l}\text { Verified } \\
\text { the text } \\
\text { fields of } \\
\text { The } \\
\text { source is } \\
\text { getting } \\
\text { the values } \\
\text { incorrect } \\
\text { format. }\end{array}$ \\
\hline $\begin{array}{l}\text { Reservati } \\
\text { on }\end{array}$ & $\begin{array}{l}\text { Verify the File } \\
\text { Name \& File } \\
\text { Size }\end{array}$ & 8 & $\begin{array}{l}\text { Ensure that the } \\
\text { text field of File } \\
\text { Name \& File }\end{array}$ & $\begin{array}{l}\text { The advance } \\
\text { application } \\
\text { should be }\end{array}$ & $\begin{array}{l}\text { 1. Open the } \\
\text { application }\end{array}$ & $\begin{array}{l}\text { Verify } \\
\text { the file } \\
\text { name \& }\end{array}$ & $\begin{array}{l}\text { Verify the } \\
\text { file name } \\
\&\end{array}$ \\
\hline
\end{tabular}




\begin{tabular}{|c|c|c|c|c|c|c|c|}
\hline & & & $\begin{array}{l}\text { Size of the } \\
\text { source. }\end{array}$ & available & $\begin{array}{l}\text { 2.Enter the data } \\
\text { into the file } \\
\text { name \& file size } \\
\text { 3. Verify the file } \\
\text { name \& file size } \\
\text { of the system. }\end{array}$ & $\begin{array}{l}\text { file size } \\
\text { of the } \\
\text { system. }\end{array}$ & $\begin{array}{l}\text { the file } \\
\text { size of the } \\
\text { system. }\end{array}$ \\
\hline $\begin{array}{l}\text { Reservati } \\
\text { on }\end{array}$ & $\begin{array}{l}\text { Verify the } \\
\text { Save Button }\end{array}$ & 9 & $\begin{array}{l}\text { Ensure that the } \\
\text { click on save } \\
\text { button file } \\
\text { search is saved } \\
\text { successfully or } \\
\text { not. }\end{array}$ & $\begin{array}{l}\text { The advance } \\
\text { application } \\
\text { should be } \\
\text { available }\end{array}$ & $\begin{array}{l}\text { 1. Open the } \\
\text { application } \\
\text { 2. Click on the } \\
\text { save button. } \\
\text { 3. Verify the } \\
\text { search of the file } \\
\text { is saved } \\
\text { successfully or } \\
\text { not. }\end{array}$ & $\begin{array}{l}\text { Verified } \\
\text { the } \\
\text { search } \\
\text { of the } \\
\text { file is } \\
\text { saved } \\
\text { successf } \\
\text { ully. }\end{array}$ & $\begin{array}{l}\text { Verified } \\
\text { the search } \\
\text { of the file } \\
\text { is saved } \\
\text { successful } \\
\text { ly. }\end{array}$ \\
\hline $\begin{array}{l}\text { Admissi } \\
\text { on } \\
\text { Control }\end{array}$ & $\begin{array}{l}\text { Verify the } \\
\text { Admission } \\
\text { Control }\end{array}$ & 10 & $\begin{array}{l}\text { Ensure that the } \\
\text { admission } \\
\text { control whether } \\
\text { retrieving the } \\
\text { data is correct or } \\
\text { not. }\end{array}$ & $\begin{array}{l}\text { The advance } \\
\text { application } \\
\text { should be } \\
\text { available }\end{array}$ & $\begin{array}{l}\text { 1. Open the } \\
\text { application } \\
2 . \\
\text { admission } \\
\text { control whether } \\
\text { retrieving the } \\
\text { data is incorrect } \\
\text { or not. }\end{array}$ & $\begin{array}{l}\text { Verified } \\
\text { the data } \\
\text { retrievin } \\
\mathrm{g} \text { is } \\
\text { correct. }\end{array}$ & $\begin{array}{l}\text { Verified } \\
\text { the data } \\
\text { Retrievin } \\
\mathrm{g} \text { is } \\
\text { correct. }\end{array}$ \\
\hline
\end{tabular}

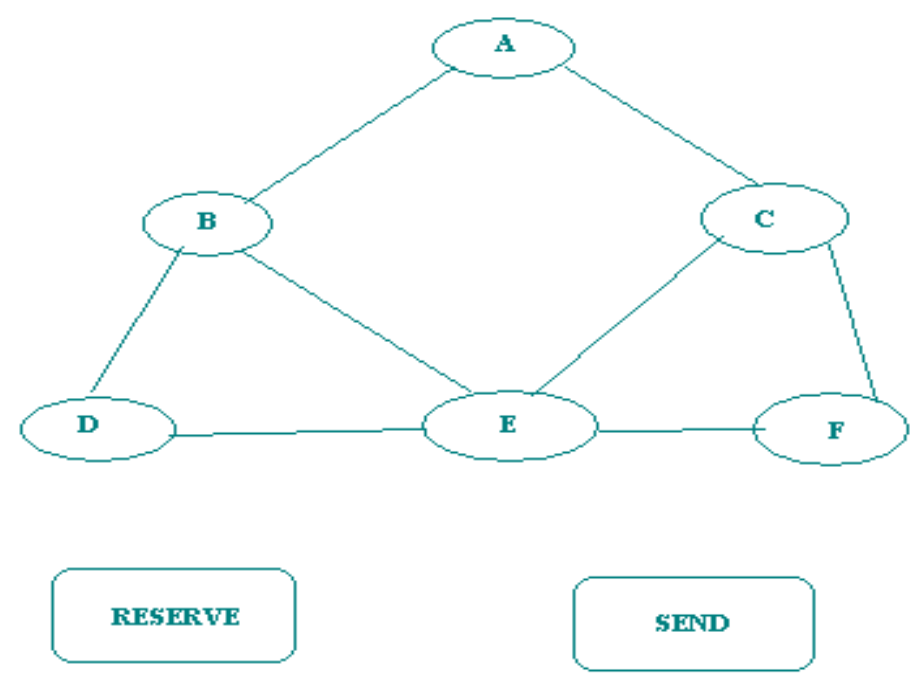

Fig. 1 The default graph existing the buttons send and reserve 


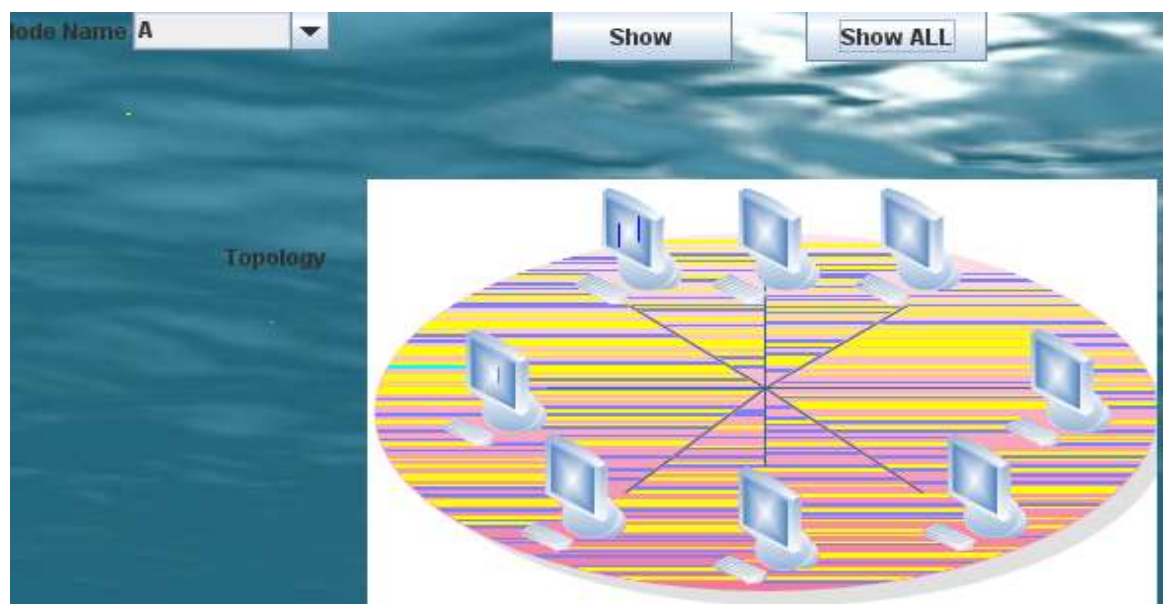

Fig. 2 The admission control shows all the reserved paths in various times in the database

\section{CONCLUSION}

This proposed technique goes for adding to the administration and asset allotment of research systems for information concentrated e-science coordinated efforts. The requirement for substantial record exchange and high-transmission capacity, lowinactivity organise ways among the principal prerequisites postured in such conditions. This selected list of routes can be used and identified for the sending and receiving fo the emergency data that can be used for the future purpose and other in near future applications and for another set of applications in the mode of service to the society and the public in the society. The open doors lie in the way that examination systems are by and large substantially littler in estimate that people in general Internet, and thus bear the cost of a brought together asset administration stage. This task consolidates the accompanying novel components into a robust system of $\mathrm{AC}$ and stream booking: early bookings for mass exchange and least transfer speed ensured movement, multipath directing, and data transmission reassignment using occasional re-enhancement. By booking or blocking some set of routes that will help us send the emergency data to the end users whenever there is a need of sending the emergency data. Hence, in this regard the selection and identification of the freely available slots and less utilised routes that was available in the total list of routes available for the data or packets of data to be transmitted from sender to receiver. To deal with begin and end time prerequisite of bookings ahead of time, additionally the headway of time, it distinguishes a liberal group of discrete time-cut structures, to be specific the logical cut structures.

\section{REFERENCES}

[1] The U.K. Research Councils, http://www.research-councils.ac.uk/e-Science/, Feb. 2008.

[2] I. Foster and C. Kesselman, the Grid: Blueprint for a New Computing Infrastructure. Morgan Kaufmann, 1999.

[3] H.B. Newman, M.H. Ellisman, and J.A. Orcutt, "Data-Intensive E-Science Frontier Research," Comm. ACM, vol. 46, no. 11, pp. 68-77, Nov. 2003.

[4] J. Bunn and H. Newman, "Data-Intensive Grids for High-Energy Physics," Grid Computing: Making the Global Infrastructure a Reality, F. Berman, G. Fox, and T. Hey, eds., John Wiley \& Sons, 2003.

[5] T. DeFanti, C.d. Laat, J. Mambretti, K. Neggers, and B. Arnaud, "Translight: A Global-Scale LambdaGrid for e-Science," Comm. ACM, vol. 46, no. 11, pp. 34-41, Nov. 2003.

[6] I. Foster, C. Kesselman, C. Lee, R. Lindell, K. Nahrstedt, and A. Roy, "A Distributed Resource Management Architecture that Supports Advance Reservations and Co-Allocation,” Proc. IFIP Seventh Int'1 Workshop Quality of Service (IWQoS), 1999.

[7] The Globus Alliance, http://www.globus.org/, Feb. 2008.

[8] T. Lehman, J. Sobieski, and B. Jabbari, "DRAGON: A Framework for Service Provisioning in Heterogeneous Grid Networks," IEEE Comm. Magazine, Mar. 2006. 